\title{
84. Die Möglichkeit des Nachweises und der Lokalisation von malignen Tumoren mit der ${ }^{67} \mathrm{Ga}$-Szintigraphie
}

\author{
S. F. GrebE *, H. Schön, R. STeckenmesser und N. HEger-Gießen
}

\section{The Detection and Location of Malignant Tumours with the Aid of ${ }^{67}$ Ga-Scintigraphy}

Summary. Two to three days after intravenous injection of 2-3 mCi Gallium 67 . citrate, one can detect and locate malignant soft-tissue tumours scintigraphically and estimate their extent. Surface tumours of a dimater of at least $0.8 \mathrm{~cm}$ and deeper-lying tumours of a diameter of $2 \mathrm{~cm}$ can be demonstrated. Malignant tumours already treated or undergoing treatment rarely take up ${ }^{67} \mathrm{Ga}$. Of 108 cases examined by us, 83 were malignant tumours, of which 57 took up ${ }^{67} \mathrm{Ga}$. In the abdominal cavity the distinction between ${ }^{67} \mathrm{Ga}$ enrichment of a tumour from the physiological ${ }^{67} \mathrm{Ga}$ of the liver and large intestine, which, however, is of different intensity, can be difficult. Often the radiogallium can be removed from the bowel by means of a purgative. The tumour can then be shown by scintigraphy on the 4th to 6 th day. Out of 52 tumours situated outside the abdominal cavity about $81 \%$ took up ${ }^{67} \mathrm{Ga} .38$ of these tumours were bronchial carcinomas and ${ }^{67} \mathrm{Ga}$ concentration was present in $91 \%$ of them. In 10 systemic diseases a ${ }^{67} \mathrm{Ga}$ enrichment was seen in 8 . In these cases the entire extent of the disease process could be followed, except inside the abdominal cavity. The affinity of ${ }^{67} \mathrm{Ga}$ to malignant tumours is not specific since non-malignant processes, through very rarely, can also show ${ }^{67} \mathrm{Ga}$ storage. This was observed in two out of fifteen cases. Total-body radiation of the tumour-free patient, at doses of $2.5 \mathrm{mCi}$, is $506 \mathrm{mrad}$, the liverradiation dosage amounting to about 1.3 rad.

Zusammenfassung. Nach i.v.-Injektion von 2-3 mCi Gallium 67-Citrat kann man 2-3 Tage später maligne Weichteiltumoren szintigraphisch nachweisen und lokalisieren und die Ausdehnung des Prozesses erkennen. Oberflächlich gelegene Tumoren mit einem Mindestdurchmesser von $0,8 \mathrm{~cm}$ und in der Tiefe gelegene mit einem von $2 \mathrm{~cm}$ sind nachweisbar. Anbehandelte oder behandelte Malignome speichern seltener ${ }^{67} \mathrm{Ga}$. Bei 108 untersuchten Fällen waren 83 maligne Tumoren, von denen $57^{67} \mathrm{Ga}$ eingelagert hatten. Im Bauchraum ist die Unterscheidung einer ${ }^{67} \mathrm{Ga}$-Anreicherung im Tumor von der physiologischen und unterschiedlich stark auftretenden ${ }^{67} \mathrm{Ga}$-Einlagerung der Leber und des Dickdarmes schwierig. Oft kann durch Abführen das Radiogallium aus dem Darm entfernt werden und der Tumor durch die Szintigraphie am 4.-6. Tag nachgewiesen werden. Von 52 Tumoren außerhalb des Bauchraumes speicherten etwa $81 \%{ }^{67} \mathrm{Ga}$. Bei 38 von diesen Fällen lag ein Bronchial-Ca vor, das in ca. $91 \%$ der Fälle eine ${ }^{67} \mathrm{Ga}$-Einlagerung zeigte. Bei 10 Systemerkrankungen war 8 mal eine ${ }^{67} \mathrm{Ga}$-Anreicherung. Hier konnte man, außer im Bauchraum, die ganze Ausdehnung des Prozesses weitgehend erkennen. Die Affinität des ${ }^{67} \mathrm{Ga}$ zu Malignomen ist nicht tumorspezifisch, da, zwar selten, auch nicht maligne Prozesse ${ }^{67} \mathrm{Ga}$ speichern, wie wir das 2 mal bei 15 Fällen sahen. Die Ganzkörperstrahlenbelastung beträgt beim tumorfreien Patienten bei Gabe von 2,5 mCi $506 \mathrm{mrad}$, die Leber wird mit etwa 1,3 rad belastet.

Sitzungsleiter: Die Angiographie beim Erwachsenen ist uns bekannt. Sie haben gezeigt, daß sie auch beim Kleinkind ihre Berechtigung hat. 